\title{
CHINA'S INTERESTS IN CENTRAL ASIAN ECONOMIES
}

\author{
LEA MELNIKOVOVÁ
}

\begin{abstract}
In Post-Soviet Central Asia, China is emerging as one of the most influential players as a result of an overall increase in its global role. The Central Asian region forms a crucial part of the Belt and Road Initiative thanks to its strategic location and natural wealth. Relations between China and Central Asian countries have been developing very dynamically over the past two decades and China has had a substantial impact on the five economies. Although the Chinese approach is quite cautious regarding politics and security, there is much greater interest in the economic side, most significantly in energy and infrastructure. The purpose of this study is to explore the key issues behind China's economic presence in the region and to determine subsequent challenges for Central Asian countries. The methodology consists of an analysis of Chinese investment characteristics in order to understand the economic consequences of the superpower's involvement in Central Asia.
\end{abstract}

Keywords: China; Central Asia; investment; debt dependency; energy security

\section{Introduction}

For several years, China has been seeking to strengthen connections and encourage economic development in Central Asia. These efforts are primarily aimed at pragmatic goals. Economic motives are linked mainly to China's interest in gaining access to new export markets (as well as developing intercontinental transportation) and ensuring its supply of natural resources. China has disrupted Russia's monopoly over the transit of natural resources from the Central Asian republics. China has also become the largest trading partner of three of them: Uzbekistan, Turkmenistan and Kyrgyzstan, and the biggest investor in Kyrgyzstan and Tajikistan. The region has much to offer in the following spheres, and China views Central Asia as:

- an important source of the energy resources required to meet the needs of the rapidly growing Chinese economy (Rasoulinezhad, 2019; Dadabayev, 2018b; Tian, 2018; Arsentyeva, 2014);

- a promising market for goods (Rasoulinezhad, 2019; Igityan, 2019; Tian, 2018);

- an alternative route for accessing international transport corridors thanks to its infrastructure potential; the Central Asian region could become a transportation hub for Eurasia (Igityan, 2019; Dadabayev, 2018b; Jaborov, 2018); 
- a region that plays a strategically important role both in ensuring China's national security and in its formation as a great world power (Dadabayev, 2018b; Vasilyev, 2015; Anufriev, 2009).

As mentioned above, China's interest in Central Asia is not merelyonly economic, but also security-based. Although the vast majority of China's population are Han, there are many other ethnic groups in China. In percentage terms, the figures may seem low, but in absolute terms, they number in their tens or hundreds of millions. It is therefore crucial for China to develop its multi-ethnic western regions which lag behind the more developed eastern ones. The western territories, especially the Xinjiang Uyghur Autonomous Region (XUAR), share a long border with the Central Asian countries (Tajikistan has a 1,344 km border with the troubled XUAR). Maintaining stability in XUAR is essential because all the gas and oil pipelines from Central Asia pass through this region, and if it were to become destabilized, would seriously damage the Chinese economy (MGIMO, 2016). The security concerns relate not only to the Uyghur population, but to the security of China's western borders generally (Volkov, 2019).

One of the main problems when attempting a proper analysis of China's economic influence in Central Asia is the absence of a comprehensive and reliable dataset containing information about China's project costs and credit terms and conditions. It makes it difficult to assess the benefits of such projects, as indicated by Caroline Freund, World Bank Director of Trade, Regional Integration and Investment Climate, when commenting on the Belt and Road Initiative (BRI) (The World Bank, 2019). The same applies to Chinese lending, a problem well documented by Horn et al. (2019).

\section{Belt and Road Initiative}

When considering key issues in the China-Central Asia relationship, the BRI cannot be ignored. In autumn 2013, Xi Jinping proposed that China and the Central Asian republics should work together to develop a modern version of the ancient Silk Road and extend mutual economic connections to support regional cooperation. He also suggested implementing large-scale infrastructure projects (Wilson, 2016).

The BRI is an enormous infrastructure project which goes beyond the mere economic dimension. It is the primary driver of the relationship between China and the Central Asian republics occupying a geostrategic position. Beijing is promoting it as a new model of international cooperation propelled by regional economic collaboration and development. The core aspects of the approach to Central Asia are improving connectivity, regional development and investment (Wu \& Pan, 2018; Pantucci, 2016). The BRI consists of bilateral approaches and an open and flexible framework, and its opacity is thought to be down to the fact that it is an evolving model (Tian, 2018). The BRI is a long-term strategy whereby China seeks to strengthen its economic position and ensure economic growth. According to Larin \& Matveev (2014), the BRI is an answer to China's economic needs that reflects its growing economic power and political expectations of a greater role in international politics. However, even before the BRI was announced, China had significantly increased its investment in infrastructural projects around the world. Dadabayev (2018a) claims that China 
is merely using the energy and transit infrastructure projects as an instrument to achieve its goals concerning security, political stabilization and economic expansion.

Development assistance is an important tool under the BRI. China's approach is different from the Western one: it does not demand human rights improvements, economic liberalization or environmental protections. China's requirements are more tangible and its capital inflows are often connected to specific conditions (Ionova, 2019; Jaborov, 2018; Tian, 2018). There are a number of features that differentiate Chinese development assistance from that of traditional donors. Firstly, it lacks clarity and transparency. Unlike the OECD Development Assistance Committee, it does not have an official definition of development aid. The Chinese do not use the terms "development assistance" or "development aid"; instead, they use the term "strategic partnership" (Tian, 2018; Kassenova, 2009). The key principle of China's development assistance is non-interference in domestic affairs. Its assistance comes in packages comprising aid, concessional loans and trade and investment deals, and often involve various requirements or implicit conditionality (Tian, 2018). For example, recipient countries seeking concessional loans for infrastructure and technical assistance projects have to agree that $50 \%$ of the companies, materials, equipment and technology used in implementation will be Chinese (Tian, 2018). The loanfor-resources scheme, whereby loans are repaid in the form of natural resources, is very popular.

Local Central Asian elites find the principle of non-interference and the opaqueness of development assistance appealing and they tend to be more receptive to the aid provided by China. However, if China gets more leverage, the Central Asian republics may become economically dependent on their powerful neighbour (Tian, 2018).

\section{China's investment}

China's investment policy in Central Asia is systemic, large-scale and long-term, and is driven by economic and strategic goals. The vast majority of Chinese investments come in the form of loans with specific terms and conditions of return. Direct lending is China's main investment tool in low-income countries, followed by FDI in commodity producing industries, transport and energy (Horn et al., 2019). This pattern is evident in the Central Asian economies, especially in the smaller and economically more vulnerable republics, Kyrgyzstan and Tajikistan. Most countries in the region are considered to be unreliable borrowers by Western countries and international organizations and so are willing to take loans from China and are already heavily dependent on them. Chinese loans constituted an insignificant share of these countries' debts until 2008 but since then the situation has changed dramatically (Jaborov, 2018).

Let us take a look at China's role in the world's capital flows and the situation of Central Asian economies in this regard. China's role in world trade is well understood and documented, unlike its growing influence in global finance. China's capital exports worldwide have expanded immensely in recent decades. Many of these financial flows are not reflected in the reports of the International Monetary Fund (IMF), the Bank for International Settlements or the World Bank (Horn et al., 2019). 
Horn et al. (2019) define three key features of Chinese capital flows which are unusual for official lending:

a) the vast majority of these flows are official (i.e. provided by the Chinese government, state-owned companies or the state-controlled central bank); at the same time, these loans often share similarities with commercial lending and are often backed by collateral;

b) China does not issue any reports on its official lending (China is not a member of the Paris Club, a group of creditor countries sharing information about their official lending) and data is missing on the debtor side as well; Horn et al. (2019) highlight the importance of "hidden" debt;

c) the types of flows differ depending on the recipient country: developed and higher middle income countries are more likely to receive portfolio debt flows, while lower income developing countries tend to be offered direct loans, typically with the features described above in (a).

These features apply to the loans provided to Central Asian republics. The collateral is usually export proceeds of raw materials and agricultural products, the right to explore a mineral deposit or to a share of the profits of state-owned enterprises. Kyrgyzstan is one of the top five countries with the highest levels of external debt towards China measured as the stock of total external debt from direct loans owed to China as share of GDP. It is a highly exposed, small economy that is geographically close to China. Laos and Cambodia are examples of other similarly exposed countries. Other Central Asian republics appear in the ranking as well-Tajikistan ranks $20^{\text {th }}$ and Turkmenistan $23^{\text {rd }}$. Uzbekistan also makes the list of top 50 recipients, coming $40^{\text {th }}$ in position, despite its reluctance to open up fully to Chinese investment. China's credits to recipient countries go to public borrowers as well as private borrowers, with the latter constituting less than 10\% (Horn et al., 2019).

The following table contains data collected by the American Enterprise Institute, one of the few sources on Chinese capital flows. The missing fields reflect the lack of data described by Horn et al. (2019) and the figures probably do not include "hidden" (unreported) debt.

Table 1. Chinese investments in the Central Asian republics (millions USD)

\begin{tabular}{|l|r|r|r|r|r|r|r|r|r|r|r|r|r|r|r|}
\hline & $\mathbf{2 0 0 5}$ & $\mathbf{2 0 0 6}$ & $\mathbf{2 0 0 7}$ & $\mathbf{2 0 0 8}$ & $\mathbf{2 0 0 9}$ & $\mathbf{2 0 1 0}$ & $\mathbf{2 0 1 1}$ & $\mathbf{2 0 1 2}$ & $\mathbf{2 0 1 3}$ & $\mathbf{2 0 1 4}$ & $\mathbf{2 0 1 5}$ & $\mathbf{2 0 1 6}$ & $\mathbf{2 0 1 7}$ & $\mathbf{2 0 1 8}$ & Total \\
\hline Kazakhstan & 4500 & 1910 & 1310 & 420 & 3540 & 2260 & 850 & 2100 & 5300 & 3220 & 2490 & 520 & 3810 & 1900 & 34130 \\
Uzbekistan & & & 990 & & & 290 & & 2270 & 460 & 620 & & 150 & 460 & 200 & 5440 \\
Kyrgyzstan & & & & & & & 390 & & & 3790 & 550 & & & & 4730 \\
Tajikistan & & 700 & & & 260 & & & 650 & & & & & & & 1610 \\
Turkmenistan & & & 150 & & 3130 & & & 2920 & & 600 & & & & & 6800 \\
\hline Central Asia & 4500 & 2610 & 2450 & 420 & 6930 & 2550 & 1240 & 7940 & 5760 & 8230 & 3040 & 670 & 4270 & 600 & 52710 \\
\hline
\end{tabular}

Source: created by author using data from the American Enterprise Institute, 2019

Table 2 shows that most Chinese investments go to the energy sector, followed by transport and the chemical industry. Although a lot of the data is missing, the energy sector is a clear leader. 
Table 2. China's investments in the Central Asian republics by industry in 2005-2018 (millions USD)

\begin{tabular}{|l|r|r|r|r|r|r|r|}
\hline & Energy & Transport & Agriculture & Chemicals & Finance & Metals & $\begin{array}{c}\text { Real } \\
\text { Estate }\end{array}$ \\
\hline Kazakhstan & 22780 & 3120 & 0 & 3680 & 110 & 2330 & 350 \\
Uzbekistan & 3490 & 460 & 290 & 440 & & 190 & 610 \\
Kyrgyzstan & 2890 & 1690 & & & & 150 & \\
Tajikistan & 750 & 560 & & & & 540 & 300 \\
Turkmenistan & 6800 & & & & & & \\
\hline Total & 36710 & 5830 & 290 & 4120 & 110 & 3210 & 1260 \\
\hline
\end{tabular}

Source: created by author using data from the American Enterprise Institute, 2019

The overwhelming majority of Chinese investments take the form of loans, and the countries most vulnerable to Chinese credit expansion are Kyrgyzstan and Tajikistan (Tian, 2018).

Poor economic performance and political turmoil in 2005 and 2010 meant Kyrgyzstan was defenceless against China's growing economic influence. The volume of accumulated Chinese investment in Kyrgyzstan between 2005 and 2018 is a significant amount given its small economy (Kuzmina, 2019). According to the Ministry of Finance, Kyrgyzstan has a public debt of 4.4 billion USD, and 3.7 billion USD of that is external debt with 1.7 billion USD loaned by China (Ministry of Finance of the Kyrgyz Republic, 2019). Another issue is the transparency of loans from China, which are now associated with major corruption scandals in Kyrgyzstan (Jaborov, 2018).

According to Tajikistan's Ministry of Finance, in mid-2019 Tajikistan had an external debt of 2.9 billion USD, or $35.9 \%$ of GDP. About 1.5 billion USD (or approx. 52\%) of its foreign debt is accounted for by loans from the Chinese government (Tajik Telegraph Agency, 2019). Ionova (2019) states that China mainly finances the Tajik economy through soft loans and grants for specific projects. China provides Tajikistan with "cheap" loans on concessional terms for 20 years or more and in return receives mineral deposits on more favourable terms than would be possible under a fair contract. All projects are under Chinese control, and, accordingly, most of the profits go to China. A typical example of resourcebacked credit is described by Ionova (2019) and Jaborov (2018) and concerns the "Verkhniy Kumarg" gold deposits in the Sughd region. These were transferred to the Chinese company TBEA to repay the debt accumulated during the modernization of the "Dushanbe-2" CHP plant. The Chinese will mine the gold until the funds invested in the power plant are returned.

Kazakhstan is least dependent on China of the five Central Asian republics in terms of external debt. FDI plays a key role, exceeding the volume of other forms of Chinese investment in the country. China is Kazakhstan's fifth largest investor behind the Netherlands, USA, Switzerland and Russian Federation (National Bank of Kazakhstan, 2019). Figure 1 shows the share of Chinese FDI in Kazakhstan. It is evident that despite 
Figure 1. FDI from China to Kazakhstan compared to total FDI (millions USD)

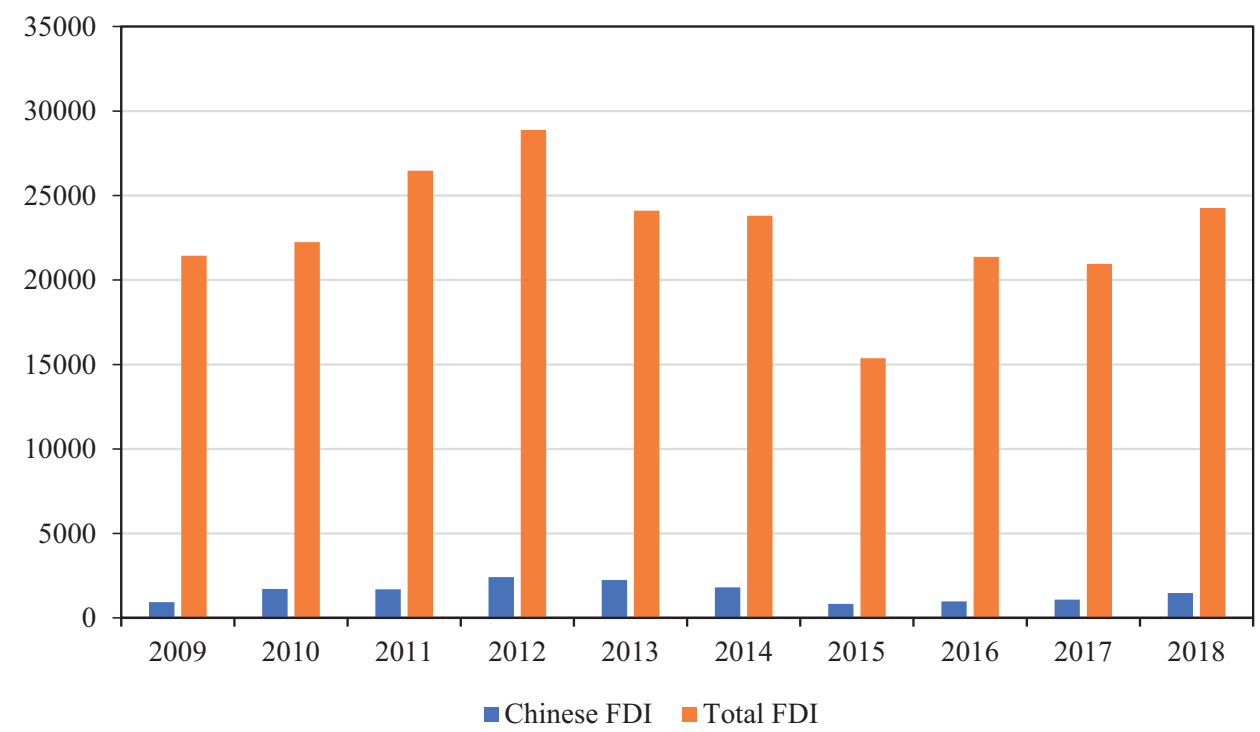

Source: External Sector Statistics. National Bank of Kazakhstan, 2019

China's proximity and economic power, Western investors are more active, except in the transport and construction sectors where China was the leading investor in 2018.

Widespread corruption is a major issue in the Central Asian countries and it adversely affects Chinese investment activity. The Corruption Perceptions Index, which measures perceived levels of public sector corruption, is low in all five countries, ranging from 19 to 34 points on a scale of 0 to 100 . Kazakhstan ranks highest and Turkmenistan lowest (Transparency International, 2020). The absence of conditionalities such as transparency, better governance, the rule of law or respect for human rights in the terms and conditions of Chinese loans encourages corruption among Central Asian elites. But China's noninterference principle makes it difficult to attribute any responsibility to China regarding the internal affairs of Central Asian republics (France, 2019).

\section{China's energy security}

Energy security is closely linked to the issues discussed in the previous section but since it plays an extremely important role in mutual relations, it deserves more attention. China's desire is to play a leading role in developing and supporting energy industries in Central Asia in order to satisfy its growing energy needs. Despite slower economic growth than in the preceding year, China's primary energy demand rose by $4.3 \%$ in 2018, the highest rate since 2012. China is the world's largest energy consumer, accounting for $24 \%$ of global energy 
Figure 2. Turkmenistan gas exports 2009-2018 (billions cubic metres)

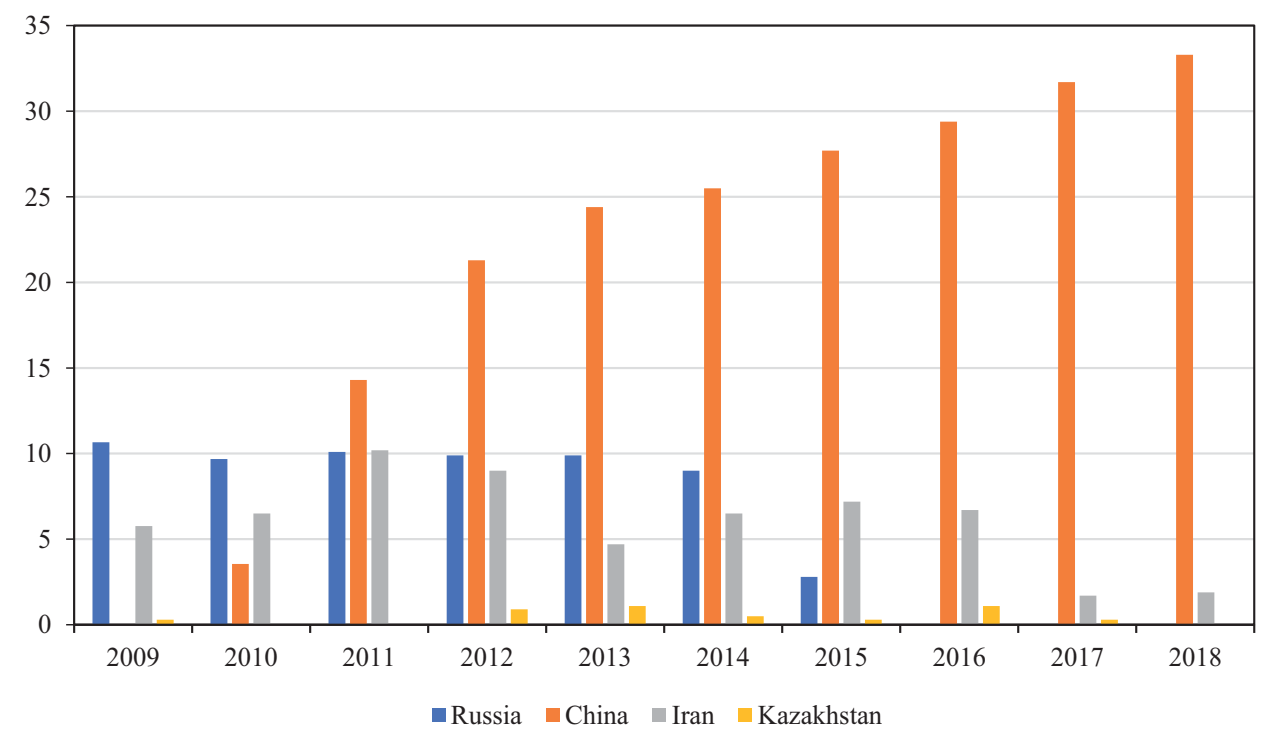

Source: created by author using data from yearly BP Statistical Reviews of World Energy, 2010-2019.

consumption and 34\% of growth in global energy demand in 2018. This made it the largest contributor to worldwide growth for the 18th consecutive year. Consumption growth in fossil fuels was highest in natural gas and oil. In 2018 China's gas consumption grew by $18 \%$ and accounted for $22 \%$ of net growth in global gas consumption. China is the world's biggest importer of oil and natural gas and in 2018 its import dependency rose to $72 \%$ on oil and to $43 \%$ on gas (BP, 2019). Concerns about energy security are increasing and China is seeking to secure access to energy resources.

In the first decade of independence, Russia was in control of the pipelines out of Central Asia, with the exception of a small gas pipeline from Turkmenistan to Iran. This monopoly did not last long, however, and China was quick to build the proposed pipelines even before the BRI had been formally announced. China changed the region's energy map, and cooperation in the energy sector has become increasingly important, mainly in relation to Kazakhstan and Turkmenistan. China built two major pipelines: an oil pipeline from Kazakhstan and a gas pipeline from Turkmenistan. The gas pipeline put an end to Turkmenistan's dependency on gas sales to Russia. The Central Asia-China gas pipeline, which started operating in 2009, has become the principal energy connection between China and Turkmenistan and is the first major example of energy cooperation in Central Asia. Kazakhstan is not only one of China's most important oil suppliers, but is also a key transit partner for natural gas from Turkmenistan. The Kazakhstan-China oil pipeline was China's first direct oil import pipeline from Central Asia. 
The most striking example of energy dependency on China is Turkmenistan. It does not share a border with China, but is interesting to Beijing mainly because of its unrivalled natural gas reserves. At the end of 2018, it was estimated that Turkmenistan had proven gas reserves of 19.5 trillion $\mathrm{m}^{3}$, considered to be the fourth largest in the world (BP, 2019). China's demand for gas is growing rapidly as a result of measures to reduce carbon emissions. It granted a 4.1 billion USD loan to develop the Galkynysh field in Turkmenistan, which is the second largest gas field in the world. China's involvement in the Turkmen gas sector is colossal: it has helped to finance pipelines and refineries and is Turkmenistan's biggest gas customer by far (Santander, 2019). In 2007 construction work began on the Central Asia-China gas pipeline, which starts in Turkmenistan and passes through Uzbekistan and Kazakhstan. Three years later, China rose from $16^{\text {th }}$ position in 2009 to become Turkmenistan's main export partner (IMF, 2019).

The vast majority of Turkmenistan's gas exports go to China and form a crucial part of its income. However, its natural gas sales to China should not be considered purely in terms of a revenue source because a significant part goes on satisfying Turkmenistan's credit obligations towards China (Invest Foresight, 2019). The following figure shows the geographic change in Turkmenistan's gas exports and China's dominance in the past decade.

As shown in Figure 2, back in 2010 Russia was the main buyer of Turkmen gas, purchasing 10 billion $\mathrm{m}^{3}$ of gas. In that same year, China, which had entered the Turkmen market a year earlier, purchased less than 5 billion $\mathrm{m}^{3}$ of gas, lagging behind Iran even, which purchased more than 6 billion $\mathrm{m}^{3}$ in 2010. However, in 2011, China overtook Iran and Russia, and to this day remains the largest buyer of Turkmen gas, purchasing more than 33 billion $\mathrm{m}^{3}$ in 2018. In 2019 Russia returned to the Turkmen market. Gazprom signed a 5-year contract with Turkmengaz allowing it to purchase up to 5.5 billion $\mathrm{m}^{3}$ of natural gas per year (Reuters, 2019).

Turkmenistan used to depend on Russia in terms of gas exports, but is now dependent on China for both gas exports and credit obligations, and is in a gas-debt trap. China is Turkmenistan's largest creditor, and a part of the debt, denominated in US dollars, is presumably being repaid in gas in current prices (the price remains a trade secret) through the loan-for-resources scheme mentioned above that China has also used in its dealings with Venezuela and Angola (Chazan, 2018, as cited in Jakóbowski \& Marszewski, 2018). Considering the high gas price when the contract was concluded, there is always the risk of price volatility and of having to supply more gas to cover the value of the repayment. In Figure 2 we can see the growing volume of Turkmen gas exports to China; however, the total value of exports in USD (consisting almost entirely of gas) fell in 2015 and 2016 as gas prices fell (IMF, 2019). Turkmenistan can now do very little to protect itself against economic deceleration in China and Russia, which are virtually its only export markets (EBRD, 2019). In order to reduce its dependency on China, Turkmenistan has been trying to diversify its energy supply routes and has been working on two projects. One is the TAPI pipeline, which will deliver Turkmen gas to Pakistan and India via Afghanistan. But construction is at risk out of fears the Afghan government will not be able to protect the pipeline. The other project is the Trans-Caspian pipeline for delivering Turkmen gas to Europe. Negotiations between the EU and Turkmenistan regarding the Trans-Caspian 
pipeline have been resumed, but Iran and Russia are opposing the project, claiming the pipeline could harm the Caspian Sea ecosystem (Hajiev, 2019).

Another important energy sector project is the planned Line D of the Central AsiaChina gas pipeline. Line D will be shorter than existing lines and pass through Uzbekistan, Tajikistan and Kyrgyzstan. The mountainous terrain in Tajikistan and Kyrgyzstan makes the project costly and, since first announced, it has been subject to changes in start dates, postponements and delays. Completion has been postponed to 2022. It has a design capacity to transport up to 30 billion $\mathrm{m}^{3}$ per year (Vollmer, 2019). There is another factor that may affect completion: the Power of Siberia pipeline delivering gas from Russia to China, which may weaken efforts to finance the construction of Line D.

\section{Transboundary water issues}

Water is another important issue in the relationship between China and the Central Asian region. Central Asia has been facing water related challenges for many decades. Since the late 1950s demand for water resources in the region has increased dramatically with the immense expansion of irrigation. Agriculture is critically dependent on irrigation, especially in Uzbekistan and Turkmenistan where cotton cultivation still plays a crucial role (Kahriz et al., 2019). Water use is heavy in both agriculture and the energy sector, mainly in the upstream countries dependent on hydroelectricity, Kyrgyzstan and Tajikistan. Cooperation among the Central Asian countries is therefore vital. Most of their territory is located in the Aral Sea basin. However, a large part of Kazakhstan lies outside it, and it draws most of its water from rivers shared with China. The two countries share 24 rivers. The most important ones are the Irtysh and Ili, both rising in China. Eighty percent of Kazakhstan's Ili Valley water originates in China and supplies much of the water inflows to Lake Balkhash, while the Irtysh is the main source of fresh water for north-eastern cities and supplies the industrial regions of central and eastern Kazakhstan (Horsman, 2003).

Tensions over water have already emerged between China and Kazakhstan due to development on both sides of the border and the associated high water demand (Russell, 2018). Kazakhstan is especially worried about the water China needs for the XUAR's expanding petroleum sector (Hongzhou, 2017). Since water problems could hamper the BRI, China needs to set an example in fairly sharing water with its neighbours. Kazakhstan should therefore benefit from the BRI in the sphere of water management. The two riparian states already have a relatively high level of institutionalized cooperation (Hongzhou, 2017). In order to diminish the risk of water disputes, China could further enhance cooperation over water use efficiencies, for example by helping modernize irrigation systems, introducing water-saving technologies and sharing knowledge about drought tolerant crops with its Central Asian neighbours, where such disputes occur.

\section{China-Russia relations}

Despite their growing closeness, China and Russia have to deal with frictions, and Central Asia is the most likely area of tensions between the two superpowers. The balance of powers in Central Asia changed around 2005 when China began implementing the first 
major projects in energy infrastructure. Russia is obviously concerned about the possibility of the region falling under China's sway, which is already happening economically, given the volume of trade and Chinese investment in Central Asia. China has replaced Russia to become Central Asia's second biggest trading partner after the EU. China imports natural resources from all five Central Asian republics and supplies them with manufactured goods, such as machinery and textiles. Intensifying economic relations with China has weakened the Central Asian republics' dependency on Russia; for example, pipelines built with China's financial assistance provide alternative routes for Central Asian oil and gas exports (Russell, 2017). From another standpoint, the new pipelines from Central Asia constructed with China's financial help have prevented the EU from accessing the Central Asian natural resources directly, and consequently Gazprom's position on the European market has remained stable (Kaczmarski, 2019).

Besides the BRI, Russia's Eurasian Economic Union (EAEU) is another regional project involving Central Asia. The parallel existence of these two projects presents a challenge to both Russia and China. The EAEU is Russia's main project in the region. Kazakhstan and Kyrgyzstan are members. The initiative has been gradually expanded, with observer status being granted to Moldova in 2018 (Eurasian Economic Commission, 2018a). Uzbekistan may be next. Since it began its political, and especially its economic reforms, the positive and negative aspects of EAEU membership have been discussed (Panfilova, 2019). Russia has chosen a different approach to Central Asia, a more institutionalized one that, unlike the Chinese project, has a developed institutional design and rules binding the participating countries (Kaczmarski, 2019).

Given the potential for conflict between Russia and China, both countries have taken measures to diminish the potential for rivalry and in May 2015 signed cooperation documents in order to balance their regional interests in Central Asia and build a framework to avoid a clash between China's BRI and Russia's EAEU among other things (Roth, 2015). The leaders of the two superpowers have adopted a Joint Declaration on Cooperation, aligning the development of the EAEU and the Silk Road Economic Belt (the part of the BRI in which Russia is a participating country). The aim is to coordinate the efforts of both projects, simplify investment procedures and develop transportation infrastructure (President of Russia, 2015). In May 2018, China signed a trade agreement with the EAEU regulating technical, sanitary and phytosanitary measures and simplifying certain customs procedures (Eurasian Economic Commission, 2018b). Although Russia's protectionist trade policy hampers the establishment of a free trade agreement with China, Chinese cargos heading to Europe and Russia through Central Asia benefit from the EAEU common customs area and the removal of customs barriers between Kyrgyzstan, Kazakhstan and Russia.

China is currently Russia's largest trading partner by far (IMF, 2020): Russia has become China's main natural gas supplier and gas flows increased significantly with the completion of the Power of Siberia pipeline. Moreover, Russia and China have agreed to avoid using US dollars where possible in mutual trade transactions, preferring domestic currencies instead (Appel, 2019). In the light of the deterioration of both US-Russian and US-Chinese relations in recent years, evident in the sanction regimes and trade wars, the Sino-Russian rapprochement makes sense. 


\section{Conclusions}

Over the last decade, relations between China and the Central Asian republics have undergone an extraordinary transformation. The penetration of Chinese capital is unprecedented and started long before the BRI was officially announced. As a result, Russia-Central Asia's traditional partner - is being displaced by China, particularly economically. Nevertheless at the moment this change in the balance of powers seems unlikely to trigger a geopolitical confrontation. Russia is concerned about China's plans, but Beijing is still counting on Moscow as the stabilizing factor in the region, and their mutual relations are more cooperative than competitive. Russia aims to transform the EAEU into one of the centres of the multipolar world and in order to do so it has to find a balance with China as a partner that respects Russia.

It is evident that cooperation before and under the BRI has brought significant benefits to the Central Asian economies, such as facilitating trade or financing for infrastructure shortfalls. However, economic engagement with China should be governed by strict principles. Given the nature of Chinese investment, using strategic assets as collateral, for example mineral deposit extraction rights, should either be duly considered or avoided. Better surveillance is key, also in terms of environmental protection, in order to make sure China uses modern, environment protection technologies in its projects. Protecting other national interests such as employing the local population, hiring domestic firms and exercising control over natural resources extraction should be a priority, along with the fight against corruption.

Not all outcomes are beneficial-contrary to claims government officials. Most countries in the region face complications stemming from China's activities, although originally they seemed attractive. Turkmenistan found a reliable gas customer and investor but has fallen into a gas-debt trap and its attempts to escape it via the TAPI and Trans-Caspian pipeline projects have not worked out yet. Tajikistan and Kyrgyzstan are very receptive to Chinese investments and would not be able to develop their industries without external support. However, the question is whether China's investments benefit Chinese industry or Central Asian industry. China hopes that economic cooperation with neighbouring Central Asian countries will bring prosperity and stability to its problematic Xinjiang region, and absorb some of its considerable excess industrial capacity. Chinese involvement seems to serve China's interests in exports, access to natural resources and transit. Moreover, servicing Chinese loans denominated in US dollars may become challenging for countries with a depreciating currency, such as Tajikistan or Kyrgyzstan. These two countries should put more effort into making their business environment and investment climate safer and more favourable in order to attract capital injections from other potential investors. In dealing with the adverse effects of its dependency on China, Turkmenistan should focus not only on completing promising projects such as TAPI, but also on diversifying its narrowly specialized economy.

The debt risks are serious, especially given the immense debt crisis in developing countries in the 1980s. The loan boom in the 1970s, during which Western banks provided credit to developing countries, ended in a series of financial crises. Considering the popular 
Chinese loan-for-resource schemes, a slump in commodity prices may have disastrous consequences for the Central Asian economies.

Future research should study both the characteristics of existing debts as well as their sustainability. Taking into consideration the opaqueness of Chinese financial flows, the international community should strongly promote transparent and competitive investments.

\section{References}

Agreement signed on trade and economic cooperation between EAEU and PRC. (2018b, May 17). Eurasian Economic Commission. Retrieved Feb 16, 2020 from http://www.eurasiancommission. org/en/nae/news/Pages/17-05-2018-5.aspx

Anufriev, K. (2009). Central Asia in China's foreign policy: A historical retrospective. Bulletin of Tomsk State University (Vestnik Tomskogo gosudarstvennogo universiteta), 324, pp. 155-157.

Appel, H. (2019). Are Xi Jinping and Vladimir Putin Partners?: Interpreting the Russia-China Rapprochement. Policy Memo No. 603. PONARS Eurasia. Retrieved Feb 12, 2020 from http:// www.ponarseurasia.org/memo/are-xi-jinping-and-vladimir-putin-partners-interpreting-russiachina-rapprochement

Arsentyeva, I. (2014). China's policy in Central Asia and Russia's strategy. News of Saratov University (Izvestiya Saratovskogo Universiteta). History Series. International Relations, 14(2), 85-89.

Belt and Road Initiative in Central Asia and the Caucasus. (2019, Mar 11). The World Bank. Retrieved Nov 16, 2019 from https://www.worldbank.org/en/news/feature/2019/03/11/belt-and-road-initiativein-central-asia-and-the-caucasus

BP Statistical Review - 2019: China's energy market in 2018. (2019). BP. Retrieved Dec 15, 2019 from https://www.bp.com/content/dam/bp/business-sites/en/global/corporate/pdfs/energy-economics/ statistical-review/bp-stats-review-2019-china-insights.pdf

BP Statistical Review of World Energy: 68th edition. (2019). BP. Retrieved Dec 15, 2019 from https:// www.bp.com/content/dam/bp/business-sites/en/global/corporate/pdfs/energy-economics/statisticalreview/bp-stats-review-2019-full-report.pdf

Chazan, Y. (2018, Jun 13). Angola's debt reliance on China may leave it short-changed. Financial Times. As cited in Jakóbowski J. and Marszewski, M. (2018). Crisis in Turkmenistan. A test for China's policy in the region. Centre for Eastern Studies. Retrieved Dec 3, 2019 from https://www. osw.waw.pl/en/publikacje/osw-commentary/2018-08-31/crisis-turkmenistan-a-test-chinas-policyregion- 0

China Global Investment Tracker. (2019). American Enterprise Institute. http://www.aei.org/chinaglobal-investment-tracker/

China's interest in Central Asia is determined by the pragmatics of national interests: Interview with Leonid Gusev. (2016, Aug 7). MGIMO. Retrieved Dec 3, 2019 from https://mgimo.ru/about/news/ experts/interes-kitaya-k-tsentralnoy-azii-obuslovlen-pragmatikoy-natsionalnykh-interesov/

Corruption Perceptions Index 2019. (2020). Transparency International. Retrieved Feb 12, 2020 from https://www.transparency.org/files/content/pages/2019_CPI_Report_EN.pdf

Dadabayev, T. (2018a). "Silk Road" as foreign policy discourse: The construction of Chinese, Japanese and Korean engagement strategies in Central Asia. Journal of Eurasian Studies, 9(1), 30-41.

Dadabayev, T. (2018b). The Chinese Economic Pivot in Central Asia and Its Implications for the PostKarimov Re-emergence of Uzbekistan. Asian Survey, 58(4), 747-769.

External Sector Statistics. (2019). National Bank of Kazakhstan. Retrieved Dec 16, 2019 from https:// nationalbank.kz/?docid $=279 \&$ switch $=$ russian

First Eastern Economic Forum. (2015, Sept 4). President of Russia. Retrieved Feb 12, 2020 from http:// en.kremlin.ru/events/president/news/50232 
Foreign business penetrates Turkmenistan. (2019, Sept 2). Invest Foresight. Retrieved Nov 30, 2019 from https://investforesight.com/foreign-business-penetrates-turkmenistan/

France, G. (2019). Kyrgyzstan: Overview of corruption and anti-corruption. Transparency International. Retrieved $16 \mathrm{Feb}, 2020$ from https://knowledgehub.transparency.org/helpdesk/ kyrgyzstan-overview-of-corruption-and-anti-corruption

Gazprom signs five-year natural gas contract with Turkmenistan. (2019, Jul 3). Reuters: Commodities. Retrieved Nov 30, 2019 from https://www.reuters.com/article/us-russia-gazprom-turkmenistandeal/gazprom-signs-five-year-natural-gas-contract-with-turkmenistan-idUSKCN1TY1X5

Hajiev, Sh. (2019, Sept 3). Turkmenistan should promote the Trans-Caspian Pipeline more actively. EURACTIV. Retrieved Nov 30, 2019 from https:/www.euractiv.com/section/azerbaijan/opinion/ turkmenistan-should-promote-the-trans-caspian-pipeline-more-actively/

Hongzhou, Zh. (2017, Feb 2). Can China solve Central Asia's impending water crisis? East Asia Forum. Retrieved Feb 12, 2020 from https://www.eastasiaforum.org/2017/02/02/can-china-solvecentral-asias-impending-water-crisis/

Horn, S., Reinhart, C., \& Trebesch, C. (2019). China's overseas lending. Kiel Working Paper No 2132. Kiel Institute for the World Economy.

Horsman, S. (2003). Transboundary water management and security in Central Asia. In J. Sperling, S. Kay, \& S. V. Papacosma (Eds.), Limiting institutions?: The challenge of Eurasian security governance. Manchester and New York: Manchester University Press.

Igityan, M. (2019). Chinese foreign policy in Central Asia and Russia's interests. Vlast'. 3, pp. 250-259.

Import and Export of Turkmenistan. (2019, Feb 13). Turkmenportal: Turkmenistan Information Portal. Retrieved Nov 30, 2019 from https://turkmenportal.com/compositions/650

Ionova, E. (2019). Tajikistan in the Orbit of Interests of China and Russia. Russia and New States of Eurasia, 3(44), 107-120.

Jaborov, S. (2018). Chinese loans in Central Asia: Development assistance or "predatory lending"? In M. Laruene (Ed.), China's Belt and Road Initiative and its Impact in Central Asia. Washington, D.C.: The George Washington University, Central Asia Program.

Kaczmarski, M. (2019, Aug 19). Russia-China relations in Central Asia: Why is there a surprising absence of rivalry? The Asan Forum. Retrieved Feb 14, 2020 from http://www.theasanforum.org/ russia-china-relations-in-central-asia-why-is-there-a-surprising-absence-of-rivalry/

Kahriz, M. P., Kahriz, P. P., \& Khawar, Kh. M. (2019). Cotton production in Central Asia. In Kh. Jabran \& B. S. Chauhan (Eds.), Cotton Production. Hoboken, NJ: John Wiley \& Sons Ltd.

Kassenova, N. (2009). China as an emerging donor in Tajikistan and Kyrgyzstan. Paris: NIS Center.

Kuzmina, E. (2019, Jul 10). The struggle for investment and grey imports: Relations between Kyrgyzstan and China. Eurasia Expert. Retrieved Dec 12, 2019 from https://eurasia.expert/ investitsii-i-seryy-import-otnosheniya-kyrgyzstana-i-kitaya/

Larin, A., \& Matveev, V. (2014). Chinese strategy of "moving West" and the "New Silk Road". Problems of the Far East (Problemy Dalnego Vostoka), 5, pp. 5-15.

Macroeconomic and Financial Data. (2019). IMF. Retrieved Dec 16, 2019 from http://data.imf. org/?sk=9D6028D4-F14A-464C-A2F2-59B2CD424B85\&sId=1515619375491

Macroeconomic and Financial Data. (2020). IMF. Retrieved Feb 16, 2020 from https://data.imf.org/ regular.aspx $?$ key $=61726508$

Panfilova, V. (2019, 2 Oct). The Eurasian Economic Union will expand thanks to Uzbekistan. Nezavisimaya gazeta. Retrieved Feb 14, 2020 from http://www.ng.ru/cis/2019-10-02/6_7691_ uzbekistan.html

Pantucci, R. (2016, Jun 20). China's Pace in Central Asia. Eurasianet. Retrieved Nov 16, 2019 from https://eurasianet.org/chinas-place-central-asia

Rasoulinezhad, E. (2019). Analyzing energy export patterns from the Commonwealth of Independent States to China: New Evidence from Gravity Trade Theory. The Chinese Economy, 52(3), 279-294. 
Roth, A. (2015, May 8). Russia and China Sign Cooperation Pacts. The New York Times. Retrieved Feb 13, 2020 from https://www.nytimes.com/2015/05/09/world/europe/russia-and-china-signcooperation-pacts.html

Russell, M. (2017). China's role in Central Asia. European Parliamentary Research Service. Retrieved Feb 12, 2020 from http://www.europarl.europa.eu/RegData/etudes/ATAG/2017/603969/EPRS_ ATA(2017)603969_EN.pdf

Russell, M. (2018). Water in Central Asia: An increasingly scarce resource. European Parliamentary Research Service. Retrieved Feb 12, 2020 from http://www.europarl.europa.eu/RegData/etudes/ BRIE/2018/625181/EPRS_BRI(2018)625181_EN.pdf

Supreme Eurasian Economic Council outcomes: Moldova granted Observer State status at the EAEU, Union countries reinforcing foundation for sustainable economic development and interaction with third countries, implementing Digital Agenda, and expanding single services market (2018a, May 14). Eurasian Economic Commission. Retrieved Feb 16, 2020 from http://www. eurasiancommission.org/en/nae/news/Pages/14-05-2018-3.aspx

The structure of the state external debt of the Kyrgyz Republic as of October 31, 2019. (2019). Ministry of Finance of the Kyrgyz Republic. Retrieved Dec 16, 2019 from http://www.minfin.kg/ru/novosti/ novosti/struktura-gosudarstvennogo-vneshnego-dolga-kr-po-s6102

The volume of loans to Tajikistan from China is about $\$ 1$ billion 525 million. (2019, Oct 28). Statement by the vice speaker of lower house of parliament of Tajikistan A. Felaliev. Tajik Telegraph Agency. Retrieved Dec 16, 2019 from https://tajikta.tj/ru/news/obem-kreditov-vtadzhikistan-iz-kitaya-sostavlyaet-okolo-1-mlrd-525-mln-

Tian, H. (2018). China's conditional aid and its impact in Central Asia. In Laruene M. (Ed.). China's Belt and Road Initiative and its Impact in Central Asia. Washington, D.C.: The George Washington University, Central Asia Program.

Turkmenistan overview. (2019). EBRD. Retrieved Nov 30, 2019 from https://www.ebrd.com/where-weare/turkmenistan/overview.html

Turkmenistan: Foreign Investment. (2019). Santander: Trade markets. Retrieved Nov 30, 2019 from https://santandertrade.com/en/portal/establish-overseas/turkmenistan/investing-3

Vasilyev, L. (2015). Some aspects of China's policy in Central Asia. China in world and regional politics. History and Modernity (Istoriya i Sovremennost), 20, 104-118.

Volkov, V. (2019, Jun 21). Does China have competitors for influence in Tajikistan? Deutsche Welle. Retrieved Nov 21, 2019 from https://www.dw.com/ru/есть-ли-у-китая-конкуренты-за-влияние-втаджикистане/a-49295322.

Vollmer, T. (2019, Nov 26). Russian gas pivots east. Petroleum Economist. Retrieved Dec 27, 2019 from: https://www.petroleum-economist.com/articles/politics-economics/europe-eurasia/2019/ russian-gas-pivots-east

Wilson, J. L. (2016). The Eurasian Economic Union and China's silk road: Implications for the Russian-Chinese relationship. European Politics and Society, 17(S1), 113-132.

Wu, Sh., \& Pan, Q. (2018). Financial cooperative potential between China and Belt and Road Countries. Emerging Markets Finance and Trade, 55(14), 3295-3310.

\author{
Metropolitan University Prague \\ Prokopova 100/16 \\ 13000 Prague 3 \\ Czech Republic \\ Email: lea.melnikovova@mup.cz
}

